\title{
Requirement of Chum Salmon Held in Freshwater for Dietary Phosphorus*1
}

\author{
Takeshi Watanabe*2, Akihiro MURAKamI ${ }^{* 2}$, Levien TAKeUCHI*2, \\ Takeshi NosE*3, and Chinkichi OGINo*2 \\ (Received October 12, 1979)
}

\begin{abstract}
Chum salmon, Oncorhynchus keta, held in freshwater and weighing an average of $1.5 \mathrm{~g}$, were fed purified diets containing different amounts of calcium and phosphorus for 7 weeks. The growth rate correlated positively with dietary phosphorus levels but not with calcium levels. Feeding a low-phosphorus diet resulted in reduced growth, low feed conversion and insufficient development of the bones. Dietary phosphorus levels greatly affected the ash, calcium and phosphorus contents of the bones. The available phosphorus level in a diet producing the maximal growth and the normal development of bones was found to be $0.5-0.6 \%$, when the rearing water contained an adequate amount of calcium.

The results obtained with fish fed diets containing white fish meal as a protein source also dernonstrated that the availability to chum salmon of the phosphorus contained in the fish meal was relatively high. Thus the supplementation of the diets containing this fish meal with primary sodium phosphate resulted in no acceleration of the growth response of the fish.
\end{abstract}

Recent $^{\text {studies }}{ }^{1-101}$ on mineral requirements of fish have demonstrated that among inorganic matters phosphorus is one of the most important nutrients for growth and normal development of bones in fish. MURAKami ${ }^{1.21}$ reported that the addition of sodium phosphate (monobasic) to carp diets containing fish meal as a protein source was effective in promoting growth and in prevention of deformity of the skull. This supplemental effect of phosphorus is satisfactorily explained by the recent results of OGino et al..$^{5,101}$ who demonstrated that the availability of phosphorus contained in fish meal was fairly low to carp compared with that to rainbow trout. The requirement of available phosphorus in diets is reported to be $0.6-0.8 \%$ in any fish species ${ }^{5,6,8)}$ and is not affected by dietary calcium levels. ${ }^{5,6)}$

Following a previous study, in which the availability of various kinds of dietary phosphorus in carp and rainbow trout was demonstrated, ${ }^{101}$ we have attempted the determination of the phosphorus requirement of chum salmon, Oncorhynchus $k e t a$, in a freshwater environment, by feeding diets containing different levels of phosphorus or calcium. The results demonstrate that the growth and the development of bones are correlated only with the dietary levels of phosphorus, and not with calcium, when the feeding experiments were carried out in the water containing an adequate amount of calcium. The results also show that the availability to chum salmon of phosphorus contained in fish meal was around $71 \%$. The requirement of chum salmon for available phosphorus required to produce maximal growth and normal skeletal formation under the present experimental conditions is proven to be $0.5-0.6 \%$ of the diet.

\section{Materials and Methods}

\section{Experimental Diet}

Feeding experiments were conducted twice (Experiments I and II). The compositions of the test diets are listed in Table 1. In Exp. I egg albumin denatured by boiling with ethyl alcohol for $5 \mathrm{~h}$ was used as a protein source. Dietary calcium and phosphorus levels were adjusted with calcium lactate and a mixture of $25 \mathrm{~g}$ of sodium phosphate $\left(\mathrm{NaH}_{2} \mathrm{PO}_{4} \cdot 2 \mathrm{H}_{2} \mathrm{O}\right)$ and $40 \mathrm{~g}$ of potassium phosphate $\left(\mathrm{KH}_{2} \mathrm{PO}_{4}\right)$ as shown in Table 2. Effects of dietary levels of potassium and sodium on the requirement for dietary phosphorus were also examined (diet 3). In Exp. II white fish meal was

*1 Mineral Requirements in Fish-IX.

*2 Laboratory of Fish Nutrition, Tokyo University of Fisheries, 5-7, Konan 4, Minato-ku, Tokyo 108

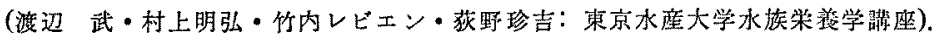

*8 The National Research Institute of Aquaculture, Hiruta, Tamaki-cho, Mie-ken 519-04, Japan

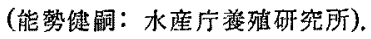


Table 1. Compositions of the experimental diets containing egg albumin (Experiment $\mathrm{I}$ ) or white fish meal (Experiment II) as protein sources (\%)

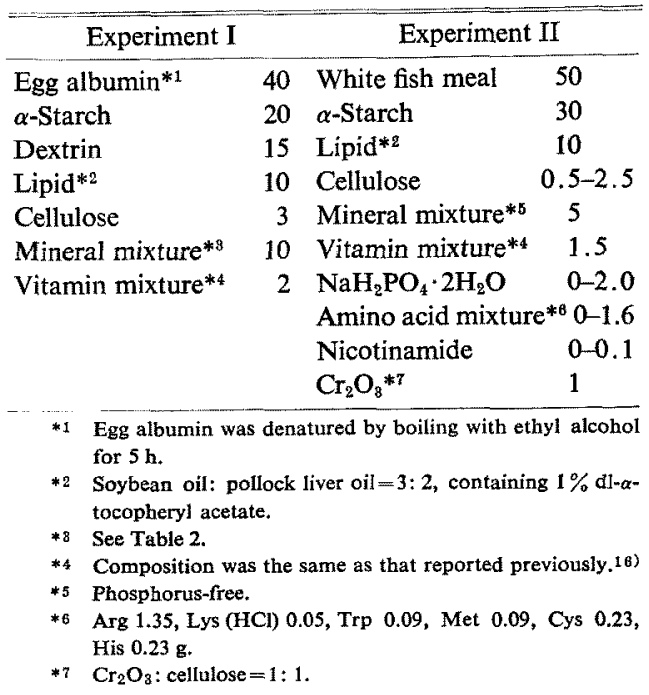

used as a protein source in order to investigate the availability of phosphorus contained in fish meal and to investigate the effect of supplemental monosodium phosphate in the fish meal diets on the growth of chum salmon (Table 7). An amino acid mixture, and nicotinamide, which were known to accelerate respectively the growth response of chum salmon* and the appetite of carp (unpublished data), were added to diets 5 and 6 in order to ex- amine the growth promoting effect of these materials in chum salmon.

The content of crude protein in the diets was determined to be $35-38 \%$ in both Exps. I and II. The composition of the mineral mixture used was essentially the same as that prepared by OGINo et $a l^{101}$ (OGno mixture) which satisfies the mineral requirements in carp and rainbow trout at a $5 \%$ dietary level. The diets were given to fish in a dry pellet form as described in the previous paper. ${ }^{111}$

\section{Fish and Feeding}

Fingerling chum salmon were used as the experimental animals. Eyed eggs obtained from the Hokkaido Salmon Hatchery (Fisheries Agency) were hatched in our laboratory and the fry were kept on a commercial diet for 3-5 months. They were then divided into 8 lots of 32 fish each in Exp. I and 6 lots of 35 fish each in Exp. II. In Exp. I fish were fed diet 5 for 2 weeks before initiation of a feeding trial in order to train the fish to accept the albumin diets. Each group of fish was held in a $30 \mathrm{l}$ glass tank supplied with city water, dechlorinated with active charcoal and adjusted to $11-16^{\circ} \mathrm{C}$ in Exp. I and $16-24^{\circ} \mathrm{C}$ in Exp. II. This rearing water was found to contain around 20 ppm calcium and 0.002 ppm phosphorus. Food was offered four times daily, and each time as long as the fish continued to eat. The periods of the feeding experiments were 7 weeks in Exp. I and 6 weeks in Exp. II. Other experimental conditions

Table 2. Composition of the mineral mixture used in Experiment I

\begin{tabular}{|c|c|c|c|c|c|c|c|c|}
\hline Diet no. & 1 & 2 & 3 & 4 & 5 & 6 & 7 & 8 \\
\hline $\mathrm{NaCl}$ & $1.0 \mathrm{~g}$ & $11.2^{\mathrm{g}}$ & $1.0^{\mathrm{g}}$ & $1.0 \mathrm{~g}$ & $1.0^{\mathrm{B}}$ & $1.0^{\mathrm{B}}$ & $1.0 \mathrm{~g}$ & $1.0^{5}$ \\
\hline $\mathrm{K}_{2} \mathrm{SO}_{4}$ & 1.0 & 30.3 & 1.0 & 1.0 & 1.0 & 1.0 & 1.0 & 1.0 \\
\hline $\mathrm{MgSO}_{4} \cdot 7 \mathrm{H}_{2} \mathrm{O}$ & 15.0 & 15.0 & 15.0 & 15.0 & 15.0 & 15.0 & 15.0 & 15.0 \\
\hline Fe-citrate & 2.5 & 2.5 & 2.5 & 2.5 & 2.5 & 2.5 & 2.5 & 2.5 \\
\hline Ca-lactate & 46.2 & 46.2 & 46.2 & 46.2 & 46.2 & 46.2 & 15.4 & 0 \\
\hline Trace element* & 1.0 & 1.0 & 1.0 & 1.0 & 1.0 & 1.0 & 1.0 & 1.0 \\
\hline $\mathrm{NaH}_{2} \mathrm{PO}_{4} \cdot 2 \mathrm{H}_{2} \mathrm{O}$ & & & & & & & & \\
\hline$(25: 40)$ & 0 & 18.5 & 18.5 & 37.0 & 65.0 & 93.0 & 65.0 & 65.0 \\
\hline Cellulose & 133.3 & 75.3 & 114.8 & 96.3 & 68.3 & 40.3 & 99.1 & 114.5 \\
\hline Total & 200 & 200 & 200 & 200 & 200 & 200 & 200 & 200 \\
\hline$\underset{\mathrm{P}}{\mathrm{mg} / 100 \mathrm{~g} \mathrm{diet}}$ & 0 & 200 & 200 & 400 & 700 & 1000 & 700 & 700 \\
\hline $\mathrm{Ca}$ & 300 & 300 & 300 & 300 & 300 & 300 & 100 & 0 \\
\hline $\mathrm{Na}$ & 20 & 280 & 80 & 120 & 200 & 280 & 200 & 200 \\
\hline $\mathrm{K}$ & 22 & 840 & 182 & 355 & 592 & 842 & 592 & 592 \\
\hline $\mathrm{Mg}$ & 73 & 73 & 73 & 73 & 73 & 73 & 73 & 73 \\
\hline
\end{tabular}

* T. Nose and T. Akryama: Oral presentation at the Annual Meeting of Japan. Soc. Sci. Fish., in April, 1979. 
Table 3. Effect of dietary levels of phosphorus on the growth rate of chum salmon in Experiment I

\begin{tabular}{|c|c|c|c|c|c|c|c|c|}
\hline \multirow{2}{*}{$\begin{array}{l}\text { Diet } \\
\text { no. }\end{array}$} & \multicolumn{2}{|c|}{ Dietary level $(\%)^{* 1}$} & \multirow{2}{*}{$\begin{array}{c}\text { Number } \\
\text { of } \\
\text { fish }\end{array}$} & \multicolumn{2}{|c|}{ Av. body wt. (g)*2 } & \multirow{2}{*}{$\begin{array}{l}\text { Growth } \\
\text { rate } \\
(\%)\end{array}$} & \multirow{2}{*}{$\begin{array}{c}\text { Feed } \\
\text { efficiency }\end{array}$} & \multirow{2}{*}{$\begin{array}{c}\text { Mortality } \\
(\%)\end{array}$} \\
\hline & $\mathbf{P}$ & $\mathrm{Ca}$ & & Initial & 7 weeks & & & \\
\hline $1^{* 3}$ & 0.07 & 0.42 & 31 & $1.6 \pm 0.20$ & $2.1 \pm 0.41$ & 34 & 0.33 & 6.5 \\
\hline 2 & 0.29 & 0.39 & 32 & $1.5 \pm 0.16$ & $3.8 \pm 0.71$ & 150 & 0.79 & 6.3 \\
\hline 3 & 0.27 & 0.41 & 32 & $1.5 \pm 0.18$ & $3.8 \pm 0.76$ & 151 & 0.78 & 0 \\
\hline 4 & 0.45 & 0.37 & 32 & $1.5 \pm 0.23$ & $4.8 \pm 0.76$ & 209 & 0.95 & 3.2 \\
\hline 5 & 0.89 & 0.36 & 32 & $1.5 \pm 0.17$ & $4.9 \pm 0.68$ & 224 & 1.01 & 0 \\
\hline 6 & 1.15 & 0.31 & 32 & $1.5 \pm 0.18$ & $4.8 \pm 0.61$ & 218 & 0.91 & 0 \\
\hline 7 & 0.89 & 0.13 & 32 & $1.5 \pm 0.18$ & $4.7 \pm 0.64$ & 224 & 0.95 & 0 \\
\hline 8 & 0.84 & 0.02 & 32 & $1.5 \pm 0.16$ & $4.9 \pm 0.66$ & 234 & 0.97 & 6.3 \\
\hline$* 1$ & & & & & 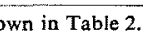 & & & \\
\hline & $\begin{array}{l}n=25 . \\
\text { iod was }\end{array}$ & & & & & & & \\
\hline
\end{tabular}

of fish care and feeding have all been described earlier. ${ }^{111}$

\section{Chemical Analyses}

At the end of the feeding trials, 25 fish were taken from each lot for determination of both proximate and mineral compositions of the fish. Lipids were extracted from the fish by the method of Folch $e t a l .{ }^{121}$ The contents of calcium and phosphorus in diets and fish bodies were determined respectively by atomic absorption spectrometry and by the method of LowERY and LOPEz. ${ }^{13 !}$ Apparent absorption of dietary phosphorus from the digestive tract determined by the indirect method using chromic oxide ${ }^{14}$ is expressed as availability of phosphorus.

\section{Results and Discussion \\ Experiment $I$}

1. Results of the feeding experiment Results of the feeding trial are summarized in Table 3 and Figs. 1-2. A close relationship between phosphorus and the growth rate up to 7 weeks was observed from the figures, indicating that the growth rate of fish was positively correlated only with dietary phosphorus levels. The growth rate was extremely low in fish kept on diet 1 (low in phosphorus) and was effectively improved by the addition of $0.45 \%$ phosphorus. The maximum weight gain was obtained at $0.5-0.6 \%$ phosphorus levels regardless of the dietary calcium levels (diets 5, 7 and 8). The feed efficiency, expressed as gain in grams per gram dry feed, is shown in Table 3 and its relation to the percentage of phosphorus in diet was also the same as that of the growth rate.

Thus, in the water containing an adequate amount of calcium, the growth of chum salmon is affected only by the dietary phosphorus levels and not by the caclium levels, as demonstrated in both carp and rainbow trout by OGINo et al. ${ }^{5,6)}$ They reported that if diets containing a very low amount of calcium and a reasonable amount of phosphorus were used, carp and rainbow trout absorbed calcium from environmental water in proportion to the amount of phosphorus absorbed through the digestive tract. A similar result was also obtained in this experiment, indicating that there was no definite relationship between the values for $\mathrm{Ca} / \mathrm{P}$ of the diets and the growth of chum salmon.

The dietary level of available phosphorus producing the maximum growth is proven to be 0.5 $0.6 \%$ of the diet as shown in Fig. 2 .

2. Signs of phosphorus deficiency As shown in Table 3, feeding with the diets containing low levels of phosphorus resulted in reduced growth and low feed efficiency regardless of the dietary

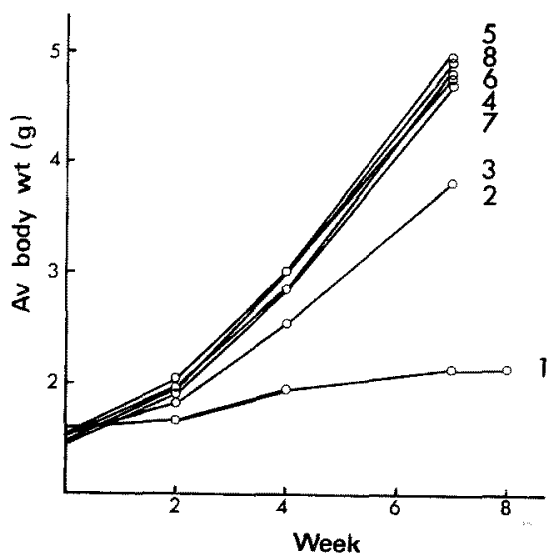

Fig. 1. Effect of dietary phosphorus levels on the growth of chum salmon. 


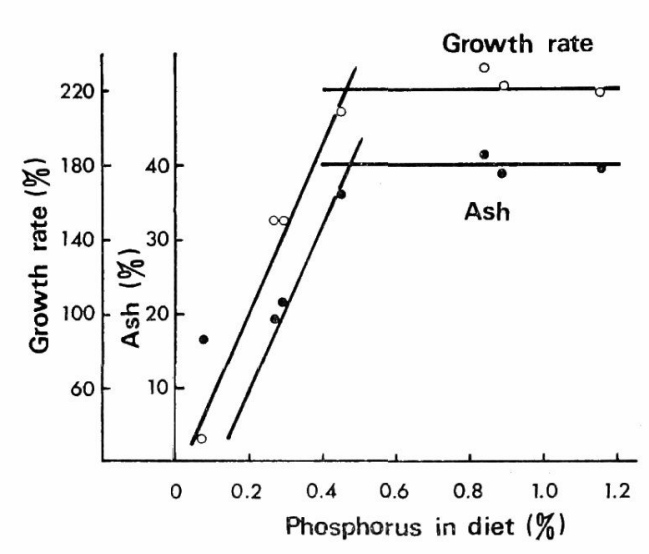

Fig. 2. Relationship between dietary phosphorus levels and the growth rate and the ash content of the bones in chum salmon.

O- O, Growth rate; - Ash content of the bones.

calcium levels. The fish on the diet without phosphorus supplement revealed deformity of the bones as the most noticeable gross external sign (Fig. 3) at the 6th week of the feeding and the abnormality of the bones attained $55 \%$ at the end of the experiment. As compared with those fed diets of adequate phosphorus levels, all of the fish showed insufficient growth of bones and had pale viscera (Fig. 4). Abnormal calcification was also observed in carp and rainbow trout fed diets low in available phosphorus. ${ }^{5,6,10)}$ Those abnormalities recognized in the bones were confirmed by the changes in the mineral composition of the bones.

3. Mineral composition The effects of dietary levels of phosphorus on the mineral compositions of the bones and whole bodies of chum salmon are summarized in Tables 4 and 5. Dietary phosphorus levels affected greately the ash, calcium and phosphorus contents both of the bones and whole bodies. In the groups fed low phosphorus diets

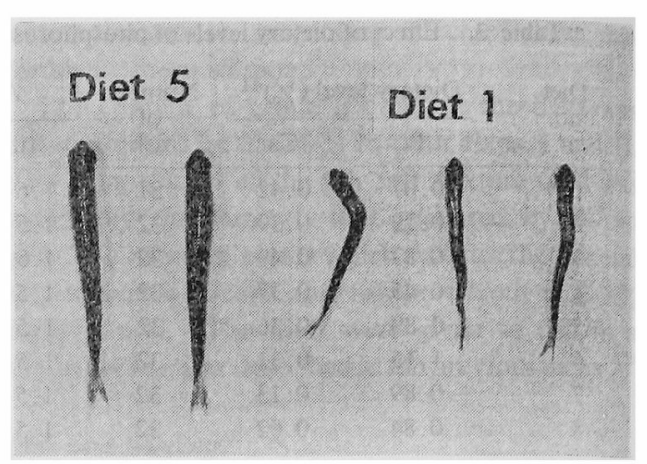

Fig. 3. Photograph showing the deformity of the bones in the fish fed the phosphorus-deficient diet (diet 1).

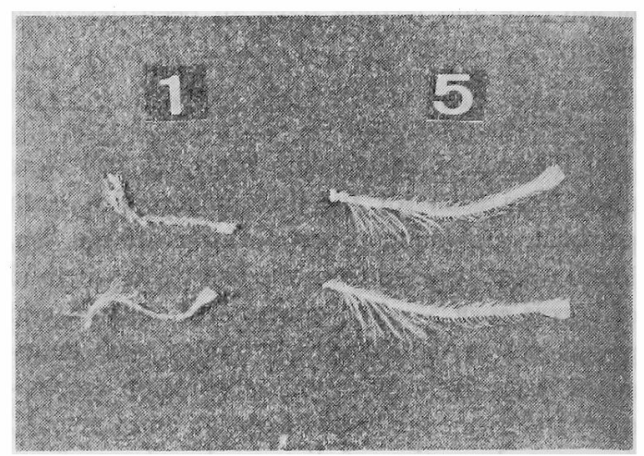

Fig. 4. Photograph showing insufficient mineralization of the bones from the fish fed the phosphorus-deficient diet (diet 1).

these mineral components, not only phosphorus but also calcium, decreased markedly regarldess of the calcium contents in the diets. These results may indicate that to utilize these elements chum salmon have an ability to balance the $\mathrm{Ca} / \mathrm{P}$ ratio of the bodies by controlling the absorption or excretion of calcium. This was indicated in carp and rainbow trout by OGINo et $a l^{5,61}$

Table 4. Effects of dietary levels of phosphorus on the mineral compositions of the bones of chum salmon in Experiment I (Lipid-free dry basis) (\%)

\begin{tabular}{ccccccccc}
\hline $\begin{array}{c}\text { Diet } \\
\text { No. }\end{array}$ & $\begin{array}{c}\text { Dietary } \\
\mathbf{P}(\%)\end{array}$ & Ash & $\mathrm{Ca}$ & $\mathrm{P}$ & $\mathrm{Ca} / \mathrm{P}$ & $\mathrm{Mg}$ & $\mathrm{Na}$ & $\mathrm{K}$ \\
\hline 1 & 0.07 & 16.4 & 4.4 & 3.3 & 1.3 & 0.2 & 0.1 & 0.6 \\
2 & 0.29 & 21.6 & 6.4 & 4.4 & 1.5 & 0.2 & 0.2 & 0.6 \\
3 & 0.27 & 19.2 & 5.6 & 4.0 & 1.4 & 0.2 & 0.2 & 0.6 \\
4 & 0.45 & 36.0 & 11.6 & 6.7 & 1.7 & 0.3 & 0.1 & 0.2 \\
5 & 0.89 & 38.8 & 13.1 & 7.8 & 1.7 & 0.3 & 0.1 & 0.1 \\
6 & 1.15 & 39.4 & 12.9 & 7.8 & 1.7 & 0.3 & 0.1 & 0.3 \\
7 & 0.89 & 38.7 & 12.3 & 7.6 & 1.6 & 0.3 & 0.1 & 0.3 \\
8 & 0.84 & 41.6 & 12.3 & 7.8 & 1.6 & 0.3 & 0.2 & 0.5 \\
\hline
\end{tabular}


Table 5. Proximate compositions of the whole bodies of chum salmon fed diets containing different amounts of phosphorus in Experiment I $(\%)$

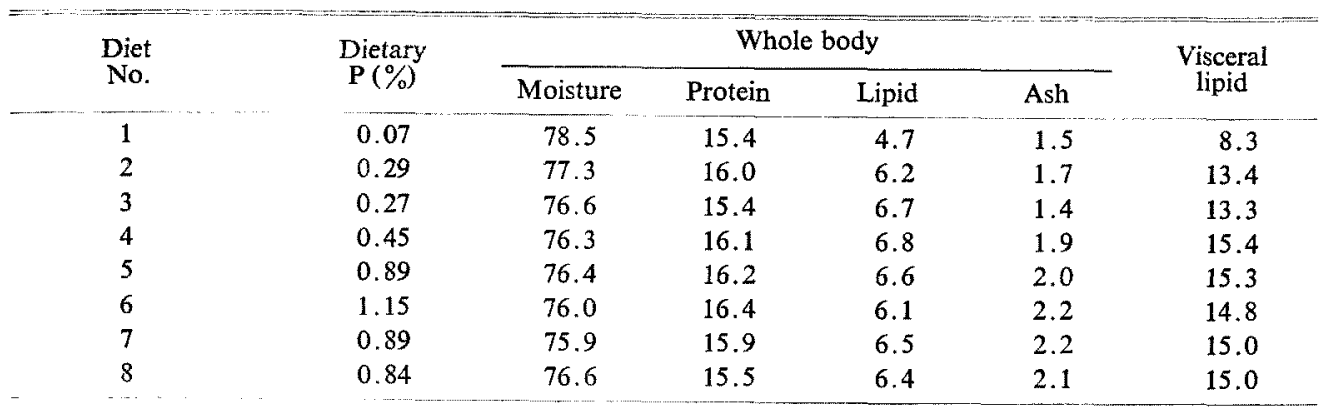

Table 6. Effects of dietary levels of phosphorus on the mineral compositions of the whole bodies of chum salmon in Experiment I (\%, wet basis)

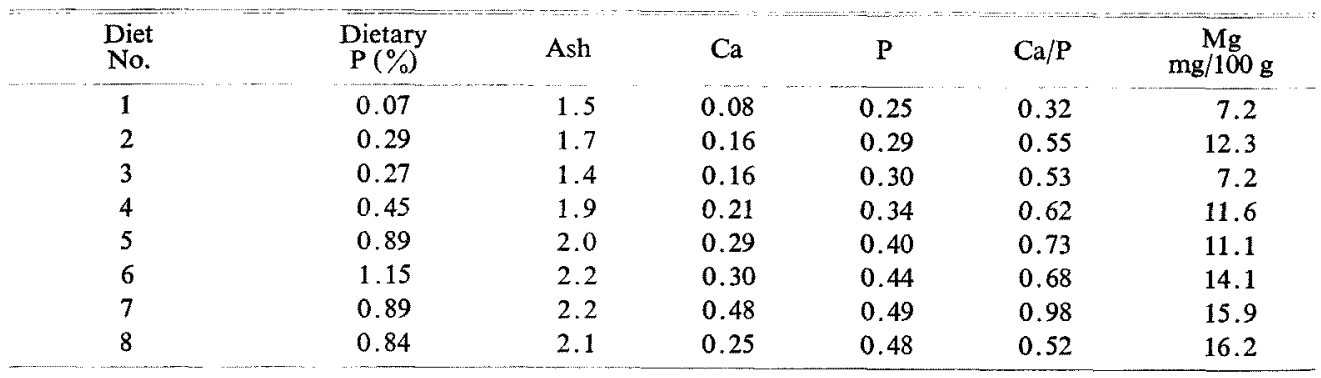

Table 7. Supplemental effect of monosodium phosphate $\left(\mathrm{NaH}_{2} \mathrm{PO}_{4} \cdot 2 \mathrm{H}_{2} \mathrm{O}\right)$ to the diet containing white fish meal in Experiment II

\begin{tabular}{|c|c|c|c|c|c|c|c|c|}
\hline \multirow{2}{*}{$\begin{array}{l}\text { Diet } \\
\text { No. }\end{array}$} & \multirow{2}{*}{$\begin{array}{l}\text { Sodium } \\
\text { phosphate } \\
\text { added to } \\
\text { diet }(\%)\end{array}$} & \multirow{2}{*}{$\begin{array}{c}\text { Total P } \\
\text { in diet } \\
(\%)\end{array}$} & \multirow{2}{*}{$\begin{array}{c}\text { P from } \\
\text { sodium } \\
\text { phosphate } \\
(\%)\end{array}$} & \multirow{2}{*}{$\begin{array}{c}\text { Number } \\
\text { of } \\
\text { fish }\end{array}$} & \multicolumn{2}{|c|}{ Av. body wt. $(g)^{* 1}$} & \multirow{2}{*}{$\begin{array}{c}\text { Growth } \\
\text { rate } \\
(\%)\end{array}$} & \multirow{2}{*}{$\begin{array}{l}\text { Feed } \\
\text { efficiency }\end{array}$} \\
\hline & & & & & Initial & 6 weeks & & \\
\hline $1 * 2$ & 0 & 1.35 & 0 & 35 & $3.2 \pm 0.81$ & $7.9 \pm 1.55$ & 144 & 0.73 \\
\hline 2 & 0.75 & 1.50 & 0.15 & 35 & $3.3 \pm 0.32$ & $7.6 \pm 2.07$ & 127 & 0.66 \\
\hline 3 & 1.36 & 1.62 & 0.27 & 35 & $3.3 \pm 0.32$ & $8.4 \pm 1.24$ & 155 & 0.72 \\
\hline $5 * 3$ & 0 & 1.35 & 0 & 35 & $3.2 \pm 0.33$ & $8.8 \pm 1.38$ & 175 & 0.75 \\
\hline $6^{* 3}$ & 0 & 1.35 & 0 & 35 & $3.2 \pm 0.36$ & $9.1 \pm 1.53$ & 180 & 0.79 \\
\hline
\end{tabular}

*1 Mean $\pm \mathrm{SD}, n=30$.

*2 Availability of Phosphorus in white fish meal determined with the diets 1,5 and 6 was found to be around $71 \%$

* Diets 5 and 6 contained $1.6 \%$ amino acid mixture and $0.1 \%$ nicotinamide, respectively.

In the fish fed low phosphorus diets the magnesium content was slightly low in both the bones and whole bodies and the potassium content was high in the bones. The same tendency was also observed for the magnesium content of the bones from fish fed the diets low in phosphorus, ${ }^{6)}$

The relationship between the dietary phosphorus levels and the ash content of the bones is shown in Fig. 2. The requirement of phosphorus for optimal bone mineralization is found to be almost the same as that for optimal growth, $0.5-0.6 \%$ in diet, slightly different from that of $\operatorname{carp}^{51}$ and channel catfish, ${ }^{15)}$ in which the phosphorus requirement for the normal calcification of the bones is above that for normal growth.

4. Proximate composition The proximate compositions of the whole bodies and the lipid contents of the viscera are indicated in Table 6 . There is no marked difference in the proximate composition of the whole bodies, except for the lipid content. The lipid content of the fish fed the diet without phosphorus supplement was low 
in both whole bodies and viscera, quite different from the case of carp in which the phosphorusdeficient diet resulted in a marked increase in the lipid content. ${ }^{51}$

\section{Experiment II}

The growth rate and feed efficiency during the 6 weeks of feeding are shown in Table 7 . The diets without phosphorus supplement were found to contain $1.35 \%$ phosphorus derived from white fish meal. As shown in Table 7, the supplementation of the diets containing white fish meal by primary sodium phosphate resulted in no acceleration of growth response of chum salmon or change in feed efficiency, although the growth rate was slightly low in the fish fed diets 1 and 2. These results indicate that the availability to chum salmon of the phosphorus contained in the fish meal is high. In fact the apparent absorption of phosphorus in the fish meal determined with diets 1,5 and 6 was found to be around $71 \%$, slightly higher than that in rainbow trout. ${ }^{10}$ This value means that the available phosphorus content in these diets is about $0.96 \%$, which satisfies the phosphorus requirement of chum salmon as demonstrated in Exp. I. The relatively higher availability of phosphorus in the fish meal probably be due to the presence of gastric juices in the stomach of the fish as suggested by OGINo et al. ${ }^{101}$ and YONE et al..$^{91}$

Diets 5 and 6 without phosphorus supplementation resulted in relatively high growth rates, suggesting the supplemental effects of the amino acid mixture and of the nicotinamide on the growth of chum salmon, respectively.

The result obtained in the feeding trial are supported by those obtained in the chemical analyses of the fish. As shown by the mineral composition of the bones in Table 8, no marked differences were observed in the contents of ash, calcium, phosphorus, magnesium and the values for $\mathrm{Ca} / \mathrm{P}$ among the experimental groups, indicating that chum salmon effectively utilize the phosphorus in the fish meal. The higher ash content of the bones in Exp. II than in Exp. I is probably due to the difference in the size of fish used in the two experiments.

In general, no difference were also observed in the proximate composition of the whole bodies and in the visceral lipid content regardless of the dietary phosphorus levels, although a high moisture content was reflected in a low lipid content in the whole body of the fish fed diet 2 , and the content of visceral lipid was low in the fish fed diet 1 (Table 9).
Table 8. Mineral compositions of the bones of chum salmon in Experiment II (Lipid-free dry basis)

\begin{tabular}{cccccc}
\hline $\begin{array}{c}\text { Diet } \\
\text { No. }\end{array}$ & Ash & $\mathrm{Ca}$ & $\mathbf{P}$ & $\mathrm{Ca} / \mathrm{P}$ & $\mathrm{Mg}$ \\
\hline 1 & 45.4 & 15.0 & 8.8 & 1.7 & 0.3 \\
2 & 46.0 & 15.0 & 8.8 & 1.7 & 0.3 \\
3 & 45.4 & 14.7 & 8.8 & 1.7 & 0.3 \\
4 & 46.3 & 14.8 & 8.6 & 1.7 & 0.3 \\
5 & 45.5 & 14.6 & 8.5 & 1.7 & 0.3 \\
6 & 44.6 & 14.0 & 8.5 & 1.7 & 0.3 \\
\hline
\end{tabular}

Table 9. Proximate compositions of the whole bodies of chum salmon in Experiment II $(\%)$

\begin{tabular}{|c|c|c|c|c|c|}
\hline \multirow{2}{*}{$\begin{array}{l}\text { Diet } \\
\text { No. }\end{array}$} & \multicolumn{4}{|c|}{ Whole body } & \multirow{2}{*}{$\begin{array}{l}\text { Visceral } \\
\text { lipid }\end{array}$} \\
\hline & Moisture & Protein & Lipid & Ash & \\
\hline 1 & 77.4 & 16.4 & 4.2 & 2.4 & 7.8 \\
\hline 2 & 79.4 & 16.9 & 2.9 & 2.5 & 11.2 \\
\hline 3 & 76.1 & 17.4 & 5.4 & 2.3 & 13.4 \\
\hline 4 & 76.3 & 16.7 & 5.4 & 2.3 & 12.7 \\
\hline 5 & 77.1 & 16.8 & 4.9 & 2.2 & 11.9 \\
\hline 6 & 77.3 & 17.8 & 4.7 & 2.0 & 10.9 \\
\hline
\end{tabular}

\section{Acknowledgement}

We express here our sincere thanks to Prof. Dr. R. G. Ackman, Nova Scotia Technical College, Canada, who kindly read the manuscript and gave valuable suggestions.

\section{References}

1) Y. Murakami: Fish Pathology, 2, 1-10 (1976).

2) Y. MuraKami: Hiroshimaken Tansuigyo Shikensho Hokoku, No. 9, 9-21; 33-45 (1970).

3) S. Arai, T. Nose, and H. Kawatsu: Bull. Freshwater Res. Lab., 24, 95-100 (1974).

4) C. Ogrno and J. Y. Chrou: Bull. Japan. Soc. Sci. Fish., 42, 71-75 (1976).

5) C. OGNo and H. TAKedA: Bull. Japan. Soc. Sci. Fish., 42, 793-799 (1976).

6) C. OGINo and H. TAKedA: Bull. Japan. Soc. Sci. Fish., 44, 1019-1022 (1978).

7) C. Ogino, F. Takashima, and J. Y. Chou: Bull. Japan. Soc. Sci. Fish., 44, 1105-1108 (1978).

8) S. SaKamoto and Y. Yone: J. Fac. Agr., Kyushu Univ., 23, 177-184 (1979).

9) Y. Yone and N. Toshima: Bull. Japan. Soc. Sci. Fish., 45, 753-756 (1979).

10) C. Ogino, L. Takeuchi, H. Takeda, and T. Watanabe: Bull. Japan. Soc. Sci. Fish., 45, 1527-1532 (1979).

11) T. Watanabe, F. Takashima, C. Ogino, and T. HibiYA: Bull. Japan. Soc. Sci. Fish., 36, 623-630 (1970). 
12) J. FolCh, M. Lees, and G. H. S. Stanley: $J$. Biol. Chem., 226, 497-509 (1959).

13) O. H. Lowry and J. Lopez: J. Biol. Chem., 162, $421-428$ (1946).

14) A. Furukawa and $\mathrm{H}$. Tsukahara: Bull. Japan.
Soc. Sci. Fish, 32, 502-506 (1966).

15) J. W. ANdrews, T. Murai, and C. Campbell: J. Nutr., 103, 766-771 (1973).

16) C. Ogino and G.-Y. YANG: Bull. Japan. Soc. Sci. Fish., 44, 1015-1018 (1978). 